\title{
ERRATUM
}

\section{Microbiomes: Gut persuasions}

Mirella Bucci

Nat. Chem. Biol. 10, 985 (2014); published online 13 November 2014; corrected after print 10 December 2014

In the version of this article initially published, the page number for the referenced article was incorrect. The error has been corrected for the PDF and HTML versions of the article.

\section{ERRATUM}

\section{Protein dynamics: Tuning disorder propensity in p53}

Richard W Kriwacki

Nat. Chem. Biol. 10, 987-988 (2014); published online 13 November 2014; corrected after print 10 December 2014

In the version of this article initially published, the journal title for reference 4 was omitted. The error has been corrected for the PDF and HTML versions of the article.

\section{CORRIGENDUM}

\section{Combating neurodegenerative disease with chemical probes and model systems}

Priyanka Narayan, Sepehr Ehsani \& Susan Lindquist

Nat. Chem. Biol. 10, 911-920 (2014); published online 17 October 2014; corrected after print 11 December 2014

In the version of this paper originally published, the 'phase' entry for PBT2 in Table 1 was inadvertently labeled as 'Discontinued'. It has now been corrected to phase 2. Additionally, at the time of this corrigendum, the U.S. Food and Drug Administration status of AZD3293 has changed to phase 2/3 on Alzforum's database of amyloid-related therapeutics, and Epothilone D has been discontinued. Lastly, BIIB037 (Aducanumab) has been announced to be proceeding to phase 3 trials. The respective table entries have been amended to reflect these changes in the HTML and PDF versions of the article.

\section{CORRIGENDUM}

\section{Solid-to-fluid DNA transition inside HSV-1 capsid close to the temperature of infection}

Udom Sae-Ueng, Dong Li, Xiaobing Zuo, Jamie B Huffman, Fred L Homa, Donald Rau \& Alex Evilevitch

Nat. Chem. Biol. 10, 861-867 (2014); published online 7 September 2014; corrected after print 4 November 2014

In the version of this article initially published, a callout made to Figure 3a should have referred to Figure 4a in the first paragraph of the subsection entitled "Solid-to-fluid DNA transition inside the HSV-1 capsid" on page 864. The error has been corrected in the HTML and PDF versions of the article. 